\title{
Three New Megastigmane Glycosides from Hylomecon vernalis
}

\author{
Seung Young Lee, Sang Un Choi, ${ }^{\dagger}$ and Kang Ro Lee* \\ Natural Products Laboratory, School of Pharmacy, Sungkyunkwan University, Suwon 440-746, Korea \\ *E-mail: krlee@skku.ac.kr \\ ${ }^{\dagger}$ Korea Research Institute of Chemical Technology, Daejeon 305-600, Korea \\ Received July 25, 2011, Accepted August 30, 2011
}

Key Words : Hylomecon vernalis, Papaveraceae, Megastigmane glycoside, Cytotoxicity

Only two Hylomecon species, H. hylomeconoides and $H$. vernalis, grow in Korea. $H$. vernalis is widely distributed in mountainous regions of Korea, and China. ${ }^{1,2} H$. vernalis has been used as Chinese folk medicine for the treatment of arthritis, neuralgia, and eczema. ${ }^{3}$ Previous phytochemical and pharmacological studies on this plant reported the isolation of several alkaloids and reported them to have antiinflammatory, antispasmodic, antimicrobial, and anti-tumoral activities. $^{3,4}$ Column chromatographic purification of the $\mathrm{BuOH}$-soluble fraction of the $\mathrm{MeOH}$ extract of the aerial parts of $H$. vernalis led to the isolation of three new megastigmane glycosides (1-3), together with four known compounds (4-7). The structures of these new compounds were elucidated on the basis of 1D and 2D NMR spectral analyses. The structures of the known compounds were identified to be $(6 R, 9 R)-3$-oxo- $\alpha$-ionyl-9- $O$ - $\alpha$-L-rhamnopyranosyl$\left(1^{\prime \prime} \rightarrow 2^{\prime}\right)$ - $\beta$-D-glucopyranoside (4), ${ }^{5} \quad(6 R, 9 R)-9$-hydroxymegastigman-4-en-3-one 9- $O$ - $\alpha$-L-rhamnopyranosyl- $\left(1 " \rightarrow 2^{\prime}\right)$ $\beta$-D-glucopyranoside (5), 3 -hydroxy-5,6-epoxy- $\beta$-ionol-9$O-\beta$-D-glucopyranoside (6), ${ }^{6}$ and megastigmane-7-ene$3,5,6,9$-tetraol-9- $O$ - $\beta$-D-glucopyranoside $(7)^{7}$ by comparing their spectroscopic data with data in the literature. The isolated compounds (1-7) were tested for cytotoxicity against four human tumor cells in vitro using a sulforhodamin B bioassay.

Compound 1 was obtained as a colorless gum. The molecular formula was determined to be $\mathrm{C}_{19} \mathrm{H}_{32} \mathrm{O}_{8}$ from the $[\mathrm{M}+\mathrm{Na}]^{+}$peak at $\mathrm{m} / z 411.1985$ (calcd. for $\mathrm{C}_{19} \mathrm{H}_{32} \mathrm{O}_{8} \mathrm{Na}$ : 411.1989) on HR-ESI-MS spectrum. The ${ }^{1} \mathrm{H}-\mathrm{NMR}$ spectrum (Table 1) of 1 displayed signals for four methyl groups at $\delta_{\mathrm{H}}$ $=1.40(3 \mathrm{H}, \mathrm{s}), 1.30(3 \mathrm{H}, \mathrm{d}, J=6.4 \mathrm{~Hz}), 1.18(3 \mathrm{H}, \mathrm{s})$, and $0.85(3 \mathrm{H}, \mathrm{s})$, two oxymethine proton signals at $\delta_{\mathrm{H}}=4.41$ $(1 \mathrm{H}, \mathrm{m})$, and $4.33(1 \mathrm{H}, \mathrm{m})$, and two olefinic proton signals at $\delta_{\mathrm{H}}=5.79(2 \mathrm{H}, \mathrm{m})$. In the ${ }^{13} \mathrm{C}-\mathrm{NMR}$ spectrum, 13 carbon signals appeared, including four methyl carbons at $\delta_{\mathrm{C}}=31.6$, $30.3,24.7$, and 20.2 , two methylene carbons at $\delta_{\mathrm{C}}=48.5$, and 47.8, two oxygenated methine carbons at $\delta_{\mathrm{C}}=76.9$, and 75.6 , two olefinic carbons $\delta_{\mathrm{C}}=133.1$, and 125.4, two oxygenated quaternary carbons at $\delta_{\mathrm{C}}=91.5$, and 81.0, and one quaternary carbon at $\delta_{\mathrm{C}}=43.3$. The ${ }^{1} \mathrm{H}-{ }^{1} \mathrm{H}$ COSY spectrum of 1 showed correlations at $\delta_{\mathrm{H}}=4.33(\mathrm{H}-3) / 1.95(\mathrm{H}-2)$ and $1.75(\mathrm{H}-4), 5.75(\mathrm{H}-8) / 5.75(\mathrm{H}-7)$ and 4.41 (H-9), $4.41(\mathrm{H}-$ 9)/5.75 (H-8) and 1.30 (H-10), indicating the presence of partial segments (see bold lines in Figure 2). In the HMBC spectrum, long-range correlations were observed between the following protons and carbons: $\mathrm{H}-2$ and $\mathrm{C}-1, \mathrm{C}-3$; H-3 and C-1, C-5, C-6; H-4 and C-2, C-6; H-7 and C-1, C-5, C9; H-8 and C-6, C-10; H-9 and C-7, C-1'; H-10 and C-8, C9; H-11, H-12 and C-1, C-2, C-6; H-13 and C-4, C-5, C-6 (Figure 2). These spectral data led us to conclude that the aglycone structure of $\mathbf{1}$ is 3,6-epoxy-7-megastigmene-5,9diol, which was isolated from tobacco. ${ }^{8,9}$ Also, the sugar moiety appeared at $\delta_{\mathrm{H}}=4.38(1 \mathrm{H}, \mathrm{d}, J=7.5 \mathrm{~Hz}), 3.82(1 \mathrm{H}$,

Table 1. ${ }^{1} \mathrm{H},{ }^{13} \mathrm{C}-\mathrm{NMR}$ data of $\mathbf{1 , 2}$ and $\mathbf{3}$

\begin{tabular}{|c|c|c|c|c|c|c|}
\hline \multirow{2}{*}{ Position } & \multicolumn{2}{|l|}{$\mathbf{1}^{a}$} & \multicolumn{2}{|l|}{$2^{a}$} & \multicolumn{2}{|l|}{$3^{a}$} \\
\hline & $\delta_{\mathrm{H}}$ & $\delta_{\mathrm{C}}$ & $\delta_{\mathrm{H}}$ & $\delta_{\mathrm{C}}$ & $\delta_{\mathrm{H}}$ & $\delta_{\mathrm{C}}$ \\
\hline 1 & & 43.3 & & 43.3 & & 43.4 \\
\hline 2 & $\begin{array}{c}1.58, \mathrm{~d}(11.7) \\
1.75, \mathrm{~m}\end{array}$ & 48.5 & $\begin{array}{c}1.58, \mathrm{~d}(11.7) \\
1.75, \mathrm{~m}\end{array}$ & 48.5 & $\begin{array}{c}1.58, \mathrm{~d}(11.7) \\
1.75, \mathrm{~m}\end{array}$ & 48.5 \\
\hline 3 & $4.33 \mathrm{~m}$ & 75.6 & $4.38, \mathrm{~m}$ & 75.7 & $4.38, \mathrm{~m}$ & 75.6 \\
\hline 4 & $\begin{array}{c}1.65, \mathrm{~d}(11.7) \\
1.95, \mathrm{~m}\end{array}$ & 47.8 & $\begin{array}{c}1.65, \mathrm{~d}(11.7) \\
1.95, \mathrm{~m}\end{array}$ & 47.8 & $\begin{array}{c}1.65, \mathrm{~d}(11.7) \\
1.95, \mathrm{~m}\end{array}$ & 47.8 \\
\hline 5 & & 81.0 & & 81.0 & & 81.0 \\
\hline 6 & & 91.5 & & 91.7 & & 91.7 \\
\hline 7 & $5.79, \mathrm{~m}$ & 125.4 & $5.76, \mathrm{~m}$ & 125.7 & $5.76, \mathrm{~m}$ & 125.7 \\
\hline 8 & & 133.1 & & 132.9 & & 132.9 \\
\hline 9 & $4.41, \mathrm{~m}$ & 76.9 & $4.38, \mathrm{~m}$ & 77.5 & $4.38, \mathrm{~m}$ & 77.5 \\
\hline 10 & $1.30, \mathrm{~d}(6.4)$ & 20.2 & $1.30, \mathrm{~d}(6.4)$ & 20.4 & $1.29, \mathrm{~d}(6.4)$ & 20.5 \\
\hline 11 & $1.40, \mathrm{~s}$ & 24.7 & $1.40, \mathrm{~s}$ & 24.7 & $1.40, \mathrm{~s}$ & 24.7 \\
\hline 12 & $0.85, \mathrm{~s}$ & 30.3 & $0.85, \mathrm{~s}$ & 30.5 & $0.85, \mathrm{~s}$ & 30.5 \\
\hline 13 & $1.18, \mathrm{~s}$ & 31.6 & $1.18, \mathrm{~s}$ & 31.6 & $1.19, \mathrm{~s}$ & 31.6 \\
\hline $1^{\prime}$ & $4.38, \mathrm{~d}(7.5)$ & 101.6 & $4.32, \mathrm{~d}(7.5)$ & 101.3 & $4.32, \mathrm{~d}(8.0)$ & 101.3 \\
\hline $2^{\prime}$ & $3.18, \mathrm{~m}$ & 74.2 & $3.18, \mathrm{~m}$ & 74.1 & $3.19, \mathrm{~m}$ & 74.1 \\
\hline $3^{\prime}$ & $3.21, \mathrm{~m}$ & 76.9 & $3.21, \mathrm{~m}$ & 76.8 & $3.21, \mathrm{~m}$ & 76.8 \\
\hline $4^{\prime}$ & $3.28, \mathrm{~m}$ & 70.3 & $3.30, \mathrm{~m}$ & 70.4 & $3.35, \mathrm{~m}$ & 70.4 \\
\hline $5^{\prime}$ & $3.35, \mathrm{~m}$ & 76.7 & $3.40, \mathrm{~m}$ & 75.5 & $3.42, \mathrm{~m}$ & 75.5 \\
\hline $6^{\prime}$ & $\begin{array}{c}3.66, \mathrm{dd} \\
(12.0,5.0) \\
3.82, \mathrm{dd} \\
(12.0,3.0)\end{array}$ & 61.5 & $\begin{array}{c}3.62, \mathrm{~m} \\
4.10, \mathrm{dd} \\
(12.0,3.0)\end{array}$ & 68.8 & $\begin{array}{c}3.61, \mathrm{~m} \\
4.12, \mathrm{dd} \\
(12.0,3.0)\end{array}$ & 68.5 \\
\hline $1 "$ & & & $4.25, \mathrm{~d}(7.5)$ & 104.3 & $4.26, \mathrm{~d}(6.5)$ & 104.4 \\
\hline $2 "$ & & & $3.28, \mathrm{~m}$ & 73.7 & $3.58, \mathrm{~m}$ & 72.8 \\
\hline $3^{\prime \prime}$ & & & $3.34, \mathrm{~m}$ & 76.4 & $3.54, \mathrm{~m}$ & 71.2 \\
\hline 4" & & & $3.48, \mathrm{~m}$ & 70.0 & $3.80, \mathrm{~m}$ & 68.3 \\
\hline $5^{\prime \prime}$ & & & $\begin{array}{l}3.19, \mathrm{~m} \\
3.85, \mathrm{~m}\end{array}$ & 65.7 & $\begin{array}{l}3.54, \mathrm{~m} \\
3.85, \mathrm{~m}\end{array}$ & 65.6 \\
\hline
\end{tabular}

${ }^{a}$ Chemical shifts in ppm relative to TMS; coupling constants $(J)$ in Hz. 


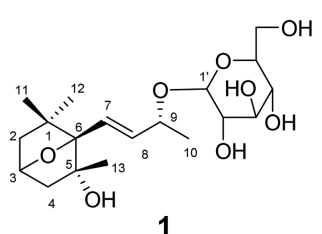

1

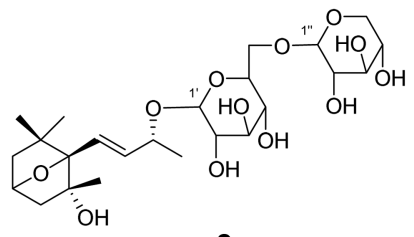

2

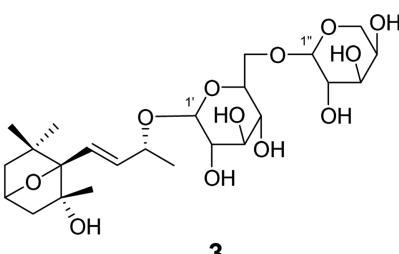

3

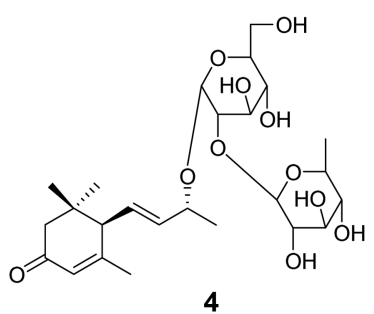

4

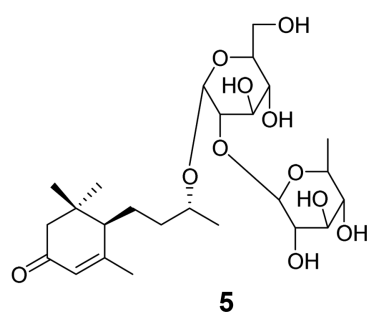

5

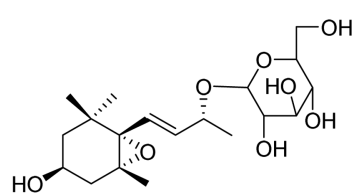

6

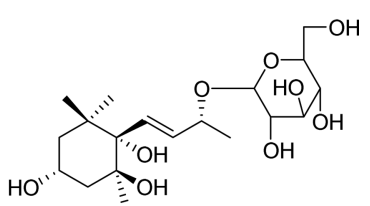

7

Figure 1. The structures of the isolated compounds 1-7 from $H$. vernalis.

dd, $J=12.0,3.0 \mathrm{~Hz}), 3.66(1 \mathrm{H}, \mathrm{dd}, J=12.0,5.0 \mathrm{~Hz}), 3.35$ $(1 \mathrm{H}, \mathrm{m}), 3.28(1 \mathrm{H}, \mathrm{m}), 3.21(1 \mathrm{H}, \mathrm{m}), 3.18(1 \mathrm{H}, \mathrm{m})$ in the ${ }^{1} \mathrm{H}-$ NMR spectrum and $\delta_{\mathrm{C}}=101.6,76.9,76.7,74.2,70.3$, and 61.5 in the ${ }^{13} \mathrm{C}$-NMR spectrum, which suggested the presence of D-glucopyranose moiety. ${ }^{10}$ The coupling constant $(J=7.5$ $\mathrm{Hz}$ ) of the anomeric proton of D-glucose indicated to be the $\beta$-form. ${ }^{10}$ The glycosidic position was established by an HMBC experiment, in which a long-range correlation was observed between the $\mathrm{H}-1^{\prime}\left(\delta_{\mathrm{H}}=4.38\right)$ of D-glucose and the $\mathrm{C}-9\left(\delta_{\mathrm{C}}=76.9\right)$ of the aglycone (Figure 2$)$. The ${ }^{1} \mathrm{H}-$ and ${ }^{13} \mathrm{C}-$ NMR, HMQC, ${ }^{1} \mathrm{H}-{ }^{-1} \mathrm{H}$ COSY, and HMBC spectra revealed that $\mathbf{1}$ had the same planar structure as crotalionoside $\mathrm{C}$ isolated from Crotalaria zanzibarica ${ }^{11}$ except for the optical rotation value. The optical rotation of $\mathbf{1}\left([\alpha]_{\mathrm{D}}^{25}:-13.0^{\circ}\right)$ was almost of the same value but of opposite sign to that of crotalionoside $\mathrm{C}\left([\alpha]_{\mathrm{D}}^{25}:+15.8^{\circ}\right)$, which suggested that compound 1 could be a stereoisomer of crotalionoside C. The relative stereochemistry of the aglycone moiety was characterized by a NOESY experiment, which showed NOE
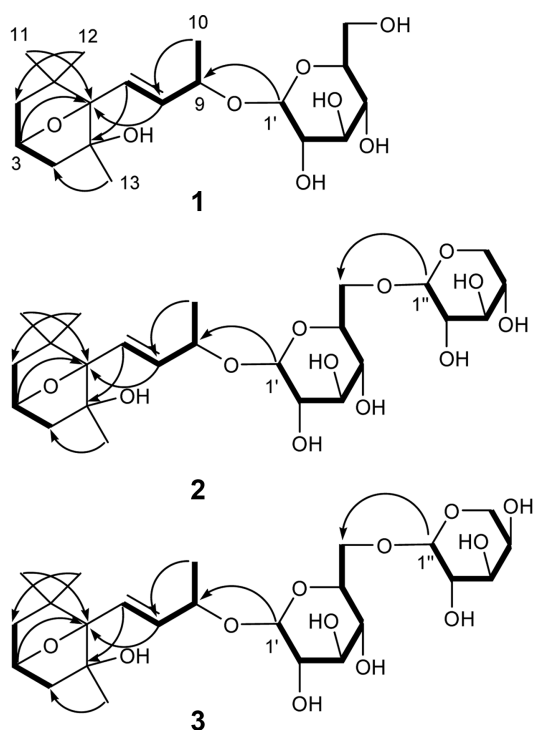

Figure 2. ${ }^{1} \mathrm{H}-{ }^{1} \mathrm{H} \mathrm{COSY}(\longrightarrow)$, and $\mathrm{HMBC}(\longrightarrow)$ correlations of 1,2 and 3 . correlations between the following proton pairs $(\mathrm{H}-2 \mathrm{a} / \mathrm{H}-4 \mathrm{a}$, and $\mathrm{H}-12 ; \mathrm{H}-2 \mathrm{~b} / \mathrm{H}-4 \mathrm{~b}$, and $\mathrm{H}-11 ; \mathrm{H}-11 / \mathrm{H}-7$ and $\mathrm{H}-3)$ as shown in Figure 3. The absolute configuration at C-9 was determined by application of a modified Mosher's method to be $R$ (Figure 4) ${ }^{11}$ But the absolute stereochemistries at $\mathrm{C}-3$, C-5 and C-6 for the ring part could not be determined. Enzymatic hydrolysis of $\mathbf{1}$ with $\beta$-glucosidase (emulsin) yielded 3,6-epoxy-7-megastigmene-5,9-diol (1a), whose ${ }^{1} \mathrm{H}$ NMR spectral data were in good agreement with values reported previously, ${ }^{8,9}$ and D-glucose. Thus, the structure of 1 was determined to be megastigmane-7-en-3,6-epoxy-5,9diol 9R- $O$ - $\beta$-D-glucopyranoside.

Compound 2 was obtained as a colorless gum. The molecular formula was determined to be $\mathrm{C}_{24} \mathrm{H}_{40} \mathrm{O}_{12}$ from the [M+ $\mathrm{Na}^{+}$peak at $m / z 543.2412$ (calcd. for $\mathrm{C}_{24} \mathrm{H}_{40} \mathrm{O}_{12} \mathrm{Na}$ : 543.2412)

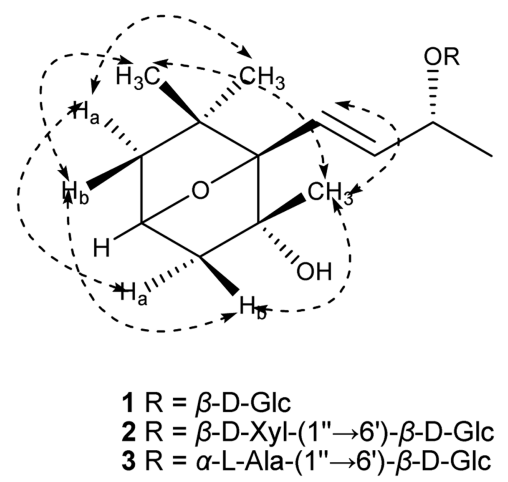

Figure 3. NOESY correlations of $\mathbf{1 , 2}$ and $\mathbf{3}$.

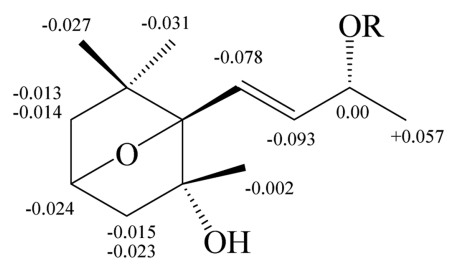

1b : $\mathrm{R}=(R)-\mathrm{MTPA}$ 1c : $\mathrm{R}=(S)$-MTPA

Figure 4. Values of $\delta_{\mathrm{S}}-\delta_{\mathrm{R}}$ of the MTPA esters of 1a. 
on HR-ESI-MS spectrum. The proton and carbon signals in the ${ }^{1} \mathrm{H}$ - and ${ }^{13} \mathrm{C}$-NMR spectra of $\mathbf{2}$ were very similar to those of 1 . The only differences were the signals from an additional sugar unit that appeared at $\delta_{\mathrm{H}}=4.25(1 \mathrm{H}, \mathrm{d}, J=7.5$ Hz, H-1"), 3.85 (1H, m), $3.48(1 \mathrm{H}, \mathrm{m}), 3.34(1 \mathrm{H}, \mathrm{m}), 3.19$ $(1 \mathrm{H}, \mathrm{m}), 3.18(1 \mathrm{H}, \mathrm{m})$ and $\delta_{\mathrm{C}}=104.3,76.4,73.7,70.0,65.7$ in the ${ }^{1} \mathrm{H}$ - and ${ }^{13} \mathrm{C}$-NMR spectra, indicating that 2 has an additional D-xylopyranose moiety. ${ }^{12}$ The coupling constant $(J=7.5 \mathrm{~Hz})$ of the anomeric proton of D-xylose indicated that it was in the $\beta$-form. ${ }^{12}$ The HMBC spectrum showed correlations between $\mathrm{H}-1^{\prime}\left(\delta_{\mathrm{H}}=4.32\right)$ of the D-glucose moiety and $\mathrm{C}-9\left(\delta_{\mathrm{C}}=77.5\right)$ of the aglycone structure, ${ }^{11}$ and between H-1" $\left(\delta_{\mathrm{H}}=4.25\right)$ of D-xylose and C-6' $\left(\delta_{\mathrm{C}}=68.8\right)$ of Dglucose (Figure 2). ${ }^{12}$ Enzymatic hydrolysis of 2 with hesperidinase yielded 2a. The NMR data of $\mathbf{2 a}$ were same to those of 1a. The sugars were confirmed to be D-glucose and D-xylose by comparison of optical rotation and GC-MS analyses. Thus, the structure of $\mathbf{2}$ was determined to be megastigmane-7-en-3,6-epoxy-5,9-diol 9R- $O$ - $\beta$-D-xylopyranosyl- $\left(1^{\prime \prime} \rightarrow 6\right.$ ')- $\beta$-D-glucopyranoside.

Compound 3 was obtained as a colorless gum. The molecular formula was determined to be $\mathrm{C}_{24} \mathrm{H}_{40} \mathrm{O}_{12}$ from the $[\mathrm{M}+\mathrm{Na}]^{+}$peak at $m / z 543.2412$ (calcd. for $\mathrm{C}_{24} \mathrm{H}_{40} \mathrm{O}_{12} \mathrm{Na}$ : 543.2419) in the HR-ESI-MS spectrum. The proton and carbon signals in the ${ }^{1} \mathrm{H}$ - and ${ }^{13} \mathrm{C}$-NMR spectra of $\mathbf{3}$ were very similar to those of $\mathbf{2}$. The major difference was the terminal sugar unit; signals from the sugar unit appeared at $\delta_{\mathrm{H}}=4.26(1 \mathrm{H}, \mathrm{d}, J=6.5 \mathrm{~Hz}, \mathrm{H}-1 "), 3.85(1 \mathrm{H}, \mathrm{m}), 3.80(1 \mathrm{H}$, $\mathrm{m}), 3.58(1 \mathrm{H}, \mathrm{m}), 3.54(2 \mathrm{H}, \mathrm{m})$ in the ${ }^{1} \mathrm{H}-\mathrm{NMR}$ spectrum and $\delta_{\mathrm{C}}=104.4,72.8,71.2,68.3,65.6$ in the ${ }^{13} \mathrm{C}$-NMR spectrum, indicating that $\mathbf{3}$ has an L-arabinopyranose moiety instead of the D-xylopyranose moiety in $2 .{ }^{13}$ The coupling constant ( $J$ $=6.5 \mathrm{~Hz}$ ) of the anomeric proton of L-arabinose indicated that it was in the $\alpha$-form. ${ }^{13}$ The positions of sugar residues in 3 were established by an HMBC experiment. The HMBC spectrum showed correlations between $\mathrm{H}-1^{\prime}\left(\delta_{\mathrm{H}}=4.32\right)$ of D-glucose and C-9 $\left(\delta_{\mathrm{C}}=77.5\right)$ of the aglycone, ${ }^{11}$ and between H-1" $\left(\delta_{\mathrm{H}}=4.26\right)$ of L-arabinose and C-6' $\left(\delta_{\mathrm{C}}=68.5\right)$ of Dglucose (Figure 2). ${ }^{13}$ Enzymatic hydrolysis of $\mathbf{3}$ with hesperidinase yielded 3a. The NMR data of 3a were same to those of 1a. The sugars were confirmed as D-glucose and Larabinose by comparison of optical rotation and GC-MS analyses. Thus, the structure of $\mathbf{3}$ was determined to be megastigmane-7-en-3,6-epoxy-5,9-diol $9 R-O$ - $\alpha$-L-arabinopyranosyl- $\left(1^{\prime \prime} \rightarrow 6\right.$ ')- $\beta$-D-glucopyranoside.

The cytotoxic activities of the isolated compounds (1-7) were evaluated by determining their inhibitory effects on human tumor cell lines (A549, SK-OV-3, SK-MEL-2, and HCT15) in vitro using the sulforhodamine B (SRB) assay. ${ }^{14}$ All the compounds showed little cytotoxicity against any tested cell line $\left(\mathrm{IC}_{50}>30 \mu \mathrm{M}\right)$.

\section{Experimental Section}

Plant Materials. The aerial parts of $H$. vernalis Maxim (Papaveraceae) (2.6 kg) were collected at Taebaek mountain in Gangwon-Do province, Korea in May 2009. A voucher specimen of the plant (SKK-09-002) was deposited at the School of Pharmacy in Sungkyunkwan University.

Extraction and Isolation. The half dried aerial parts of $H$. vernalis Maxim (Papaveraceae) (2.6 kg) were extracted with $80 \% \mathrm{MeOH}$ three times at room temperature. The resultant $\mathrm{MeOH}$ extracts $(240 \mathrm{~g})$ were suspended in distilled water $(800 \mathrm{~mL} \times 3)$ and then successively partitioned with $n$ hexane, $\mathrm{CH}_{2} \mathrm{Cl}_{2}$, EtOAc and $n-\mathrm{BuOH}$, yielding $40 \mathrm{~g}, 1 \mathrm{~g}, 3 \mathrm{~g}$ and $30 \mathrm{~g}$, respectively. The $n-\mathrm{BuOH}$ soluble fraction $(30 \mathrm{~g})$ was chromatographed on a Diaion HP-20, eluting a gradient solvent system of $100 \% \mathrm{H}_{2} \mathrm{O}$ and $100 \% \mathrm{MeOH}$ to give two fractions (Fraction A-B). Fraction B (8 g) was separated over a silica gel column (230-400 mesh, $360 \mathrm{~g})$ with a solvent system of $\mathrm{CHCl}_{3} / \mathrm{MeOH} / \mathrm{H}_{2} \mathrm{O}(15: 4: 0.5-6: 4: 1)$ as the eluent to give thirteen fractions (fr. B1-B13). Fr. B4 (240 $\mathrm{mg}$ ) was purified by preparative reversed-phase HPLC, using a solvent system of $45 \% \mathrm{MeOH}$ to obtain $6(22 \mathrm{mg})$ and 1 $(10 \mathrm{mg})$. Fr. B5 (180 mg) was purified by preparative normalphase HPLC, using a solvent system of $\mathrm{CHCl}_{3} / \mathrm{MeOH}(7: 1)$ to give $4(6 \mathrm{mg})$ and $\mathbf{5}(7 \mathrm{mg})$. Fr. B6 $(280 \mathrm{mg})$ was purified by preparative reversed-phase HPLC, using a solvent system of $53 \% \mathrm{MeOH}$ to obtain 2 (5 mg). Fr. B7 (980 mg) was purified by preparative reversed-phase HPLC, using a solvent system of $50 \% \mathrm{MeOH}$ to furnish 3 (5 mg). Fr. B8 (500 mg) was purified by preparative normal-phase HPLC, using a solvent system of $\mathrm{CH}_{2} \mathrm{Cl}_{2} / \mathrm{MeOH}$ (4:1) to obtain 7 (6 mg).

Megastigmane-7-en-3,6-epoxy-5,9-diol 9R- $\boldsymbol{O}$ - $\boldsymbol{\beta}$-D-glucopyranoside (1): Colorless gum. $[\alpha]_{\mathrm{D}}^{25}:-13.0^{\circ}$ (c 0.04 , $\mathrm{MeOH}) ; \mathrm{IR}(\mathrm{KBr}) v_{\max } \mathrm{cm}^{-1}: 3402,2965,1642,1530,1024$, 673; ${ }^{1} \mathrm{H}$ - NMR ( $\left.\mathrm{CD}_{3} \mathrm{OD}, 500 \mathrm{MHz}\right)$ : see Table $1 ;{ }^{13} \mathrm{C}-\mathrm{NMR}$ ( $\mathrm{CD}_{3} \mathrm{OD}, 125 \mathrm{MHz}$ ): see Table 1; HR-ESI-MS $m / z=411.1985$ $[\mathrm{M}+\mathrm{Na}]^{+}$(calcd for: 411.1989).

Megastigmane-7-en-3,6-epoxy-5,9-diol 9R-O- $\beta$-D-xylopyranosyl-(1" $\rightarrow$ 6')- $\beta$-D-glucopyranoside (2): Colorless gum. $[\alpha]_{\mathrm{D}}^{25}:-10.0^{\circ}(c 0.06, \mathrm{MeOH})$; IR $(\mathrm{KBr}) v_{\max } \mathrm{cm}^{-1}$ : 3402, 2963, 1648, 1529, 1026, 672; ${ }^{1} \mathrm{H}-\mathrm{NMR}\left(\mathrm{CD}_{3} \mathrm{OD}, 500\right.$ $\mathrm{MHz})$ : see Table $1 ;{ }^{13} \mathrm{C}-\mathrm{NMR}\left(\mathrm{CD}_{3} \mathrm{OD}, 125 \mathrm{MHz}\right)$ : see Table 1; HR-ESI-MS $m / z=543.2412[\mathrm{M}+\mathrm{Na}]^{+}$(calcd for: $^{2}$ 543.2412).

Megastigmane-7-en-3,6-epoxy-5,9-diol 9R-O- $\alpha$-L-arabinopyranosyl-(1" $\rightarrow$ 6')- $\beta$-D-glucopyranoside (3): Colorless gum. $[\alpha]_{\mathrm{D}}^{25}:-16.0^{\circ}(c 0.2, \mathrm{MeOH})$; IR $(\mathrm{KBr}) v_{\max } \mathrm{cm}^{-1}$ : 3383, 2947, 2837, 1649, 1459, 1026, 672; ${ }^{1} \mathrm{H}-\mathrm{NMR}\left(\mathrm{CD}_{3} \mathrm{OD}\right.$, $500 \mathrm{MHz}$ ): see Table $1 ;{ }^{13} \mathrm{C}-\mathrm{NMR}\left(\mathrm{CD}_{3} \mathrm{OD}, 125 \mathrm{MHz}\right)$ : see Table 1; HR-ESI-MS $m / z=543.2419[\mathrm{M}+\mathrm{Na}]^{+}$(calcd for: $^{2}$ 543.2412).

Enzymatic Hydrolysis of 1, 2 and 3 Compound 1 (1.0 $\mathrm{mg}$ ) with $1 \mathrm{~mL}$ of $\mathrm{H}_{2} \mathrm{O}$ and $4 \mathrm{mg}$ of $\beta$-glucosidase (Emulsin) was stirred at $37^{\circ} \mathrm{C}$ for 8 days, and then extracted with $\mathrm{CHCl}_{3}$ three times, and the $\mathrm{CHCl}_{3}$ extract was evaporated in vacuo. The $\mathrm{CHCl}_{3}$ extract $(0.5 \mathrm{mg})$ was purified using Silica HPLC $\left(\mathrm{CHCl}_{3}: \mathrm{MeOH}=10: 1\right)$ to afford an aglycone 1a as a colorless gum $[\alpha]_{\mathrm{D}}^{25}: 10.0^{\circ}(c 0.03, \mathrm{MeOH}),{ }^{1} \mathrm{H}-\mathrm{NMR}\left(\mathrm{CDCl}_{3}\right.$, $500 \mathrm{MHz})$. The sugar in water layer was identified as Dglucose by co-TLC (EtOAc: $\mathrm{MeOH}: \mathrm{H}_{2} \mathrm{O}=9: 3: 1, \mathrm{R}_{\mathrm{f}}$ value: 0.2 ) with a D-glucose standard (Aldrich Co., USA). Each compound 2-3 (each $1.0 \mathrm{mg}$ ) with $1 \mathrm{~mL}$ of $0.2 \mathrm{M}$ citrate 
buffer ( $\mathrm{pH} 4$ ) and hesperidinase (each $10 \mathrm{mg}$ ) was stirred at $42{ }^{\circ} \mathrm{C}$ for 5 days. After cooling, the reaction mixture was extracted with $\mathrm{CHCl}_{3}$. The $\mathrm{CHCl}_{3}$ extract $(2.0 \mathrm{mg})$ was purified using Silica HPLC $\left(\mathrm{CHCl}_{3}: \mathrm{MeOH}=10: 1\right)$ to afford aglycones $2 \mathrm{a}$ as a colorless gum $[\alpha]_{\mathrm{D}}^{25}: 8.0^{\circ}(c 0.04, \mathrm{MeOH})$, ${ }^{1} \mathrm{H}-\mathrm{NMR}\left(\mathrm{CDCl}_{3}, 500 \mathrm{MHz}\right)$ and $\mathbf{3 a}$ as a colorless gutm $[\alpha]_{\mathrm{D}}^{25}: 16.0^{\circ}(c 0.06, \mathrm{MeOH}),{ }^{1} \mathrm{H}-\mathrm{NMR}\left(\mathrm{CDCl}_{3}, 500 \mathrm{MHz}\right)$.

1a. $[\alpha]_{\mathrm{D}}^{25}: 10.0^{\circ}(c 0.03, \mathrm{MeOH}) ;{ }^{1} \mathrm{H}-\mathrm{NMR}\left(\mathrm{CDCl}_{3}, 500\right.$ MHz): $\delta 6.30$ (1H, dd, $J=16.0,5 \mathrm{~Hz}, \mathrm{H}-7), 6.20(1 \mathrm{H}, \mathrm{d}, J=$ 16.0, H-8), 4.65 (1H, m, H-9), $4.40(1 \mathrm{H}, \mathrm{m}, \mathrm{H}-3), 2.06(1 \mathrm{H}$,

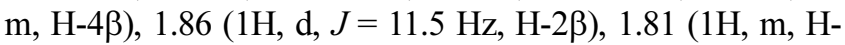
$4 \alpha), 1.71(3 \mathrm{H}, \mathrm{s}, \mathrm{H}-11), 1.66(1 \mathrm{H}, \mathrm{d}, J=11.5 \mathrm{~Hz}, \mathrm{H}-2 \alpha)$, 1.51 (3H, s, H-13), 1.45 (3H, d, $J=6.5 \mathrm{~Hz}, \mathrm{H}-10), 1.06(3 \mathrm{H}$, $\mathrm{s}, \mathrm{H}-12)$.

2a. $[\alpha]_{\mathrm{D}}^{25}: 8.0^{\circ}(c \quad 0.04, \mathrm{MeOH}) ;{ }^{1} \mathrm{H}-\mathrm{NMR}\left(\mathrm{CDCl}_{3}, 500\right.$ MHz): $\delta 6.25$ (1H, dd, $J=16.0,5 \mathrm{~Hz}, \mathrm{H}-7), 6.17(1 \mathrm{H}, \mathrm{d}, J=$ 16.0, H-8), 4.61 (1H, m, H-9), 4.36 (1H, m, H-3), $2.06(1 \mathrm{H}$,

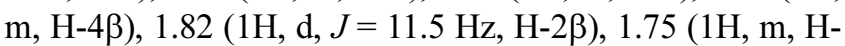
$4 \alpha), 1.67$ (3H, s, H-11), $1.62(1 \mathrm{H}, \mathrm{d}, J=11.5 \mathrm{~Hz}, \mathrm{H}-2 \alpha)$, 1.47 (3H, s, H-13), 1.41 (3H, d, $J=6.5 \mathrm{~Hz}, \mathrm{H}-10), 1.02$ (3H, $\mathrm{s}, \mathrm{H}-12)$.

3a. $[\alpha]_{\mathrm{D}}^{25}: 16.0^{\circ}(c 0.06, \mathrm{MeOH}) ;{ }^{1} \mathrm{H}-\mathrm{NMR}\left(\mathrm{CDCl}_{3}, 500\right.$ MHz): $\delta 6.29$ (1H, dd, $J=16.0,5 \mathrm{~Hz}, \mathrm{H}-7), 6.20(1 \mathrm{H}, \mathrm{d}, J=$ 16.0, H-8), 4.65 (1H, m, H-9), 4.39 (1H, m, H-3), $2.08(1 \mathrm{H}$, $\mathrm{m}, \mathrm{H}-4 \beta), 1.86(1 \mathrm{H}, \mathrm{d}, J=11.5 \mathrm{~Hz}, \mathrm{H}-2 \beta), 1.81$ (1H, m, H$4 \alpha), 1.71(3 \mathrm{H}, \mathrm{s}, \mathrm{H}-11), 1.66(1 \mathrm{H}, \mathrm{d}, J=11.5 \mathrm{~Hz}, \mathrm{H}-2 \alpha)$, $1.51(3 \mathrm{H}, \mathrm{s}, \mathrm{H}-13), 1.45$ (3H, d, $J=6.5 \mathrm{~Hz}, \mathrm{H}-10), 1.00$ (3H, s, H-12).

Determination of the Sugars of Compounds 2-3 Each sugar (each ca. $0.5 \mathrm{mg}$ ) obtained from the hydrolysis of 2-3 was dissolved in anhydrous pyridine $(0.1 \mathrm{~mL})$ and $\mathrm{L}-$ cysteine methyl ester hydrochloride $(2 \mathrm{mg})$ was added. The mixture was stirred at $60{ }^{\circ} \mathrm{C}$ for $1.5 \mathrm{~h}$. After the reaction mixture was dried in vacuo, the residue was trimethylsilylated with 1-trimethylsilylimidazole $(0.1 \mathrm{~mL})$ for $2 \mathrm{~h}$. The mixture was partitioned between $n$-hexane and $\mathrm{H}_{2} \mathrm{O}(0.3$ $\mathrm{mL}$ each), and the organic layer $(1 \mu \mathrm{L})$ was analyzed by GCMS. ${ }^{15}$ Identification of D-glucose, D-xylose, and L-arabinose for $\mathbf{2}$ and $\mathbf{3}$ were detected in each case by co-injection of the hydrolysate with standard silylated samples, giving single peaks at D-glucose (10.11 min), and D-xylose (5.54 $\mathrm{min})$ of 2, and D-glucose (10.19 $\mathrm{min})$, and L-arabinose (5.39 $\mathrm{min}$ ) of 3. Retention times of authentic samples treated in the same way with 1-trimethylsilylimidazole in pyridine, were Dglucose (10.04 $\mathrm{min})$, D-xylose (5.55 $\mathrm{min})$, and L-arabinose (5.41 min).

Preparation of the $(R)$-MTPA Ester and the (S)-MTPA Ester from 1a Compound 1a $(1.0 \mathrm{mg})$, in deuterated pyridine $(0.2 \mathrm{~mL})$, was transferred to a clean NMR tube. $(S)$ (+)- $\alpha$-(trifluoromethyl)phenylacetyl chloride $(7 \mu \mathrm{L})$ was immediately added under a $\mathrm{N}_{2}$ gas stream, and the NMR tube was permitted to stand at room temperature overnight. When the reaction was completed, it afforded the ( $R$ )-MTPA ester derivative (1b) of 1a. In the same manner as described for $\mathbf{1 b}$, the $(S)$-MTPA ester derivative (1c) of 1a was obtain- ed. The ${ }^{1} \mathrm{H}-\mathrm{NMR}$ spectra of $\mathbf{1 b}$, and $\mathbf{1 c}$ were measured in the NMR reaction tubes.

1b. ${ }^{1} \mathrm{H}-\mathrm{NMR}$ (Pyridine- $\left.d_{5}, 500 \mathrm{MHz}\right): \delta 0.968(3 \mathrm{H}, \mathrm{s}, \mathrm{H}-$ 12), 1.288 (3H, d, $J=6.5, \mathrm{H}-10), 1.465$ (3H, s, H-13), 1.639 $(1 \mathrm{H}, \mathrm{d}, J=11.5, \mathrm{H}-2 \mathrm{a}), 1.693(3 \mathrm{H}, \mathrm{s}, \mathrm{H}-11), 1.781(1 \mathrm{H}, \mathrm{m}$, H-4a), 1.849 (1H, d, $J=11.0, \mathrm{H}-2 \mathrm{~b}), 2.047$ (1H, m, H-4b), $4.384(1 \mathrm{H}, \mathrm{m}, \mathrm{H}-3), 5.776$ (1H, m, H-9), 6.057 (1H, dd, $J=$ $15.8,7.6, \mathrm{H}-8), 6.259$ (1H, d, $J=7.6, \mathrm{H}-7)$.

1c. ${ }^{1} \mathrm{H}-\mathrm{NMR}$ (Pyridine- $\left.d_{5}, 500 \mathrm{MHz}\right): \delta 0.937(3 \mathrm{H}, \mathrm{s}, \mathrm{H}-$ 12), 1.345 (3H, d, $J=6.5, \mathrm{H}-10), 1.463$ (3H, s, H-13), 1.625 $(1 \mathrm{H}, \mathrm{d}, J=11.5, \mathrm{H}-2 \mathrm{a}), 1.666(3 \mathrm{H}, \mathrm{s}, \mathrm{H}-11), 1.758(1 \mathrm{H}, \mathrm{m}$, H-4a), 1.836 (1H, d, $J=11.0, \mathrm{H}-2 \mathrm{~b}), 2.032$ (1H, m, H-4b), $4.360(1 \mathrm{H}, \mathrm{m}, \mathrm{H}-3), 5.776$ (1H, m, H-9), 5.964 (1H, dd, $J=$ $15.8,7.6, \mathrm{H}-8), 6.181$ (1H, d, $J=7.6, \mathrm{H}-7)$.

Acknowledgments. This research was supported by the Basic Science Research Program through the National Research Foundation of Korea (NRF) funded by the Ministry of Education, Science and Technology (20100029358). We thank Drs. E. J. Bang, S. G. Kim, and J. J. Seo at the Korea Basic Science Institute for their aid in obtaining the NMR and mass spectra.

Supporting Information. The spectral data of compounds 1-3, the general experimental procedures, and bioassays protocols are available on request from the correspondence author.

\section{References}

1. Lee, Y. N. Flora of Korea; Kyo-Hak Publishing Co., Seoul, 1996; p 237.

2. Bae, K. H. The Medicinal Plant of Korea; Kyo-Hak Publishing Co., Seoul, 2000; p 268.

3. Kim, S. W.; In, D. S.; Kim, T. J.; Liu, J. R. Plant Cell, Tissue Organ Cult. 2003, 74.

4. Kang, J. S.; Long, P. H.; Lim, H. M.; Kim, Y. H.; Blaschke, G. Arch. Pharm. Res. 2003, 26, 114.

5. Yu, L. L.; Hu, W. C.; Ding, G.; Li, R. T.; Wei, J. H.; Zou, Z. M.; Wang, M. H. J. Nat. Prod. 2011, 74, 1009.

6. Sudo, H.; Ide, T.; Otsuka, H.; Hirata, E.; Takushi, A.; Shinzato, T.; Takeda, Y. Chem. Pharm. Bull. 2000, 48, 542.

7. Sueyoshi, E.; Liu, H.; Matsunami, K.; Otsuka, H.; Shinzato, T.; Aramoto, M.; Takedam, Y. Phytochemistry 2006, 67, 2483.

8. Behr, D.; Wahlberg, I.; Nishida, T.; Enzell, C. R. Acta Chem. Scand. 1979, 33, 701.

9. Takagi, Y.; Fujimori, T.; Hata, T.; Kaneko, H.; Kato, K. Agric. Biol. Chem. 1980, 44, 705.

10. Perkins, S. J.; Johnson, L. N.; Phillips, D. C. Carbohydr. Res. 1977, 59, 19.

11. Shitamoto, J.; Matsunami, K.; Otsuka, H.; Shinzato, T.; Takeda, Y. Chem. Pharm. Bull. 2010, 58, 1026.

12. Ito, H.; Kobayashi, E.; Li, S. H.; Hatano, T.; Sugita, D.; Kubo, N.; Shimura, S.; Itoh, Y.; Yoshida, T. J. Nat. Prod. 2001, 64, 737.

13. Nakamura, S.; Zhang, Y.; Pongpiriyadacha, Y.; Wang, T.; Matsuda, H.; Yoshikawa, M. Heterocycles 2008, 75, 131.

14. Skehan, P.; Stroreng, R.; Scudiero, D.; Monks, A.; Mcmahon, J.; Vistica, D.; Warren, J. T.; Bokesch, H.; Kenney, S.; Boyd, M. R. J. Nat. Cancer Inst. 1990, 82, 1107.

15. Jiang, W.; Li, W.; Han, L.; Liu, L.; Zhang, Q.; Zhang, S.; Nikaido, T.; Koike, K. J. Nat. Prod. 2006, 69, 1577. 